\title{
PENGATURAN PERIZINAN REKLAMASI PANTAI TERHADAP PERLINDUNGAN LINGKUNGAN HIDUP
}

\author{
Moch. Choirul Huda \\ Kantor Advokat Huda dan Associates Surabaya \\ e-mail: huda_associates78@yahoo.com
}

\begin{abstract}
ABSTRAK
Reklamasi merupakan bentuk campur tangan (intervensi) manusia terhadap keseimbangan lingkungan alamiah yang selalu dalam keadaan seimbang dinamis. Perubahan ini akan melahirkan perubahan ekosistem seperti perubahan pola arus, erosi dan sedimentasi pantai, berpotensi meningkatkan bahaya banjir. Kajian cermat dan komprehensif tentu bisa menghasilkan area reklamasi yang aman terhadap lingkungan di sekitarnya. Otonomi daerah sebagaimana yang tertuang dalam ketentuan undang-undang merupakan landasan yang kuat bagi Pemerintah Daerah untuk mengimplementasikan pembangunan wilayah laut mulai dari aspek perizinan, perencanaan, pemanfaatan, pengawasan dan pengendalian.
\end{abstract}

Kata Kunci: reklamasi pantai, perizinan, perlindungan lingkungan hidup.

\begin{abstract}
Reclamation is a form of human intervention to the balance of the natural environment which are always in a dynamic state of balance. This change will resulting changes in ecosystems such as changes in current patterns, coastal erosion and sedimentation, and potentially increasing the danger of flooding. Careful and comprehensive assessment can certainly produce a reclaimed area that is safe for the surrounding environment. Regional autonomy as set forth in the legislation is a strong foundation for the local governments to implement the construction of the marine areas development from aspects of permitting, planning, utilization, monitoring and control.
\end{abstract}

Keywords: reclamation, authorization, environmental protection.

\section{PENDAHULUAN}

Pemekaran kota menjadi alasan utama reklamasi sehingga alternatif reklamasi pantai dilakukan karena berbagai alasan berkaitan dengan peningkatan jumlah penduduk akibat dari pertambahan penduduk alami maupun migrasi dan kesejahteraan penduduk yang miskin mendorong mereka yang semula tinggal di tengah kota memilih ke daerah pinggiran atau tempat baru untuk dapat memulai usaha demi meningkatkan kesejahteraannya serta penyebaran keramaian kota, semula semua kegiatan terpusat di kota sehingga dibutuhkan ruang baru untuk menampung semua kegiatan yang mana tidak bisa difasilitasi dalam kota (Departemen Kelautan dan Perikanan, 2001:19). Kegiatan reklamasi pantai sebenarnya bukan hanya untuk mendapatkan lahan murah, tetapi juga untuk lebih meningkatkan fungsi sekaligus memperbaiki keadaan yang tidak diinginkan. Misalnya, bila suatu daerah telah sering banjir karena pasang laut atau air hujan menjadi tidak banjir.

Kota-kota besar di Indonesia merupakan kotakota pantai dengan jumlah penduduk yang besar dan kegiatan perekonomian yang pesat, tetapi seringkali lahan yang tersedia tidak mendukung pertumbuhan dan perkembangan wilayah kota tersebut (http:// www.ld-feui.org/page.php?lang=id\&menu=news view\&news id=155). Lahan menjadi terasa sangat sempit untuk dapat memenuhi kebutuhan kota untuk perkantoran dan pemukiman, lokasi perindustrian, pelabuhan dan fasilitas sosial lainnya seperti pusat perdagangan, hiburan dan wisata. Wilayah pesisir yang mana berada di bawah kewenangan pengelolaan daerah seringkali mendorong Pemerintah Daerah untuk mewujudkan ruang baru sebagai tempat untuk berbagai aktifitas.

Realita tersebut mendorong wilayah yang ada di pinggir pantai untuk terus mencari alternatif baru sebagai tempat menampung kegiatan perkotaan. Pada dasarnya, reklamasi pantai dilakukan sebagai upaya untuk memperluas wilayah daratan dengan berbagai tujuan yang sah dan telah dipraktekkan secara luas di seluruh dunia. Upaya manusia mempertimbangkan akan terbatasnya daratan sebagai tempat aktifitas utama manusia, baik sebagai sarana pemukiman, industri, perdagangan dan lain sebagainya. 
Kebutuhan dan juga manfaat reklamasi dapat dilihat dari aspek tata guna lahan, aspek pengelolaan pantai dan ekonomi (M. Farchan, 2008:4). Tata ruang suatu wilayah tertentu kadang membutuhkan untuk direklamasi agar dapat berdaya dan berhasil guna. Untuk pantai yang diorientasikan bagi pelabuhan, industri, wisata ataupun pemukiman yang perairan pantainya dangkal wajiblah untuk direklamasi agar bisa dimanfaatkan. Terlebih kalau di area pelabuhan itu, reklamasi menjadi suatu kebutuhan mutlak untuk pengembangan fasilitas pelabuhan, tempat bersandar kapal, pelabuhan peti-peti kontainer, pergudangan dan mengurangi kepadatan yang menumpuk di kota dan menciptakan wilayah yang bebas dari penggusuran karena berada di wilayah yang sudah disediakan oleh pemerintah dan pengembang, tidak berada di bantaran sungai maupun pantai.

Kegiatan reklamasi pantai sangat memungkinkan timbulnya dampak yang diakibatkan. Adapun untuk menilai dampak tersebut bisa dibedakan dari tahapan yang dilaksanakan dalam proses reklamasi, yaitu: Pertama, Tahap Pra Konstruksi, antara lain meliputi kegiatan survei teknis dan lingkungan, pemetaan dan pembuatan pra rencana, perizinan, pembuatan rencana detail atau teknis. Kedua, Tahap Konstruksi, kegiatan mobilisasi tenaga kerja, pengambilan material urug, transportasi material urug, proses pengurugan. Ketiga, Tahap Pasca Konstruksi, yaitu kegiatan demobilisasi peralatan dan juga tenaga kerja, pematangan lahan, pemeliharaan lahan.

Melihat ruang lingkup tahapan tersebut, maka wilayah yang kemungkinan terkena dampak adalah: Pertama, wilayah pantai yang semula merupakan ruang publik bagi masyarakat itu akan hilang atau berkurang karena akan dimanfaatkan kegiatan privat. Dari sisi lingkungan banyak biota laut yang mati baik flora maupun fauna karena timbunan tanah urugan sehingga mempengaruhi ekosistem yang sudah ada. Kedua, sistem hidrologi gelombang air laut yang jatuh ke pantai akan berubah dari alaminya. Berubahnya alur air akan mengakibatkan daerah diluar reklamasi akan mendapat limpahan air yang banyak sehingga kemungkinan akan terjadinya abrasi, tergerus atau mengakibatkan terjadinya banjir atau rob karena genangan air yang banyak dan lama. Ketiga, aspek sosialnya, kegiatan masyarakat di wilayah pantai sebagian besar adalah sebagai petani tambak, nelayan ataupun buruh.

Dengan adanya reklamasi ini akan mempengaruhi ikan yang ada di laut, sehingga nanti akan berakibat pada menurunnya pendapatan mereka yang tentunya menggantungkan hidup kepada laut. Selanjutnya adalah aspek ekologi, kondisi ekosistem di wilayah pantai yang kaya akan keanekaragaman hayati sangat mendukung fungsi pantai sebagai penyangga daratan. Ekosistem perairan pantai sangat rentan terhadap perubahan sehingga apabila terjadi perubahan baik secara alami maupun rekayasa akan mengakibatkan berubahnya keseimbangan ekosistem.

Ketidakseimbangan ekosistem perairan pantai dalam waktu yang relatif lama ini akan berakibat pada kerusakan ekosistem wilayah pantai, kondisi ini menyebabkan kerusakan pantai. Dampak yang ditimbulkan daripada tempat pengambilan material urug (Jacob Rais dkk, 2004:103). Untuk reklamasi biasanya hanyalah memerlukan material urug yang cukup besar yang tidak dapat diperoleh dari sekitar pantai, sehingga harus didatangkan dari wilayah lain yang memerlukan jasa angkutan. Pengangkutan ini berakibat pada padatnya arus lalu lintas, penurunan kualitas udara, debu, bising yang akan mengganggu kesehatan masyarakat.

Dampak positif kegiatan reklamasi antara lain terjadinya peningkatan kualitas dan nilai ekonomi kawasan pesisir, mengurangi lahan yang dianggap kurang produktif, penambahan wilayah, perlindungan pantai dari erosi, peningkatan kondisi habitat perairan, penyerapan tenaga kerja dan lain-lain. Sedangkan dampak negatif dari proses reklamasi pada lingkungan meliputi dampak fisik seperti halnya perubahan hidrooseanografi, sedimentasi, peningkatan kekeruhan air, pencemaran laut, peningkatan potensi banjir dan genangan di wilayah pesisir, rusaknya habitat laut dan ekosistemnya. Selain itu, reklamasi juga akan berdampak pada perubahan sosial ekonomi seperti kesulitan akses publik ke pantai, berkurangnya mata pencaharian (Jennefer Laidley, 2005:196).

Berdasar dari deskripsi latar belakang masalah di atas, maka dapatlah dirumuskan permasalahan bagaimana pengaturan perizinan reklamasi pantai terhadap perlindungan lingkungan hidup.

\section{PEMBAHASAN}

Reklamasi merupakan suatu upaya untuk mencari alternatif tempat untuk dapat menampung kegiatan perkotaan seperti pemukiman, industri, perkantoran untuk mendukung daya dukung dan kembang kota. Sejak diundangkannya Undang-Undang No. 32 Tahun 2004 tentang Pemerintahan Daerah menjabarkan bahwa kewenangan daerah dalam mengelola wilayah lautnya. Otonomi daerah sebagaimana yang tertuang dalam ketentuan undang-undang di atas merupakan landasan yang kuat bagi Pemerintah Daerah untuk dapat mengimplementasikan pembangunan wilayah 
laut mulai dari aspek perencanaan, pemanfaatan, pengawasan, pengendalian (Ali Maskur, 2008:8).

Kewenangan daerah atas wilayah laut mencakup pengaturan administrasi, tata ruang dan penegakan hukum yang berkenaan dengan kegiatan eksplorasi, eksploitasi, konservasi, dan pengelolaan kekayaan laut. Selain itu, daerah juga berwenang memberikan bantuan penegakan keamanan dan kedaulatan negara. Yurisdiksi berlaku kewenangan daerah atas laut dibagi atas dua, yakni wilayah laut provinsi dan wilayah laut Kabupaten/Kota. Kewenangan Propinsi atas laut sejauh 12 mil laut diukur dari garis pantai ke arah laut lepas atau ke arah perairan kepulauan. Sedangkan wilayah laut Kabupaten/Kota adalah sepertiga dari batas laut daerah Propinsi.

Pengakuan legislasi terhadap proses desentralisasi pengurusan wilayah laut diteruskan oleh Peraturan Pemerintah No. 25 Tahun 2000 tentang Kewenangan Pemerintah dan Kewenangan Propinsi sebagai Daerah Otonom. PP ini mengatur pembagian kewenangan antara Pemerintah Pusat dengan Pemerintah Propinsi. Semua jenis kewenangan, yang tidak disebutkan didalam PP ini, menjadi kewenangan Kabupaten/ Kota. Rupanya dalam hal penentuan kewenangan Kabupaten/Kota, PP ini menggunakan teori residu. Dalam aturan PP ini kewenangan propinsi dipilah ke dalam kewenangan lintas Kabupaten/Kota dan kewenangan di bidang tertentu. Salah satu bidang tertentu yang dimaksud adalah laut. Menurut PP ini, propinsi berwenang atas laut dalam hal melakukan: Penataan dan pengelolaan perairan di wilayah laut Propinsi; Eksplorasi, eksploitasi, konservasi, dan pengelolaan kekayaan laut, sebatas wilayah laut itu. Kewenangan Propinsi; Konservasi dan pengelolaan plasma nutfah spesifik lokasi serta suaka perikanan di wilayah laut kewenangan Propinsi; Pelayanan izin usaha pembudidayaan dan penangkapan ikan pada perairan laut di wilayah laut kewenangan Propinsi; Pengawasan akan pemanfaatan sumber daya ikan di wilayah laut kewenangan Propinsi.

Di dalam ketentuan dari Undang-Undang No. 32 Tahun 2004 tentang Pemerintahan Daerah, sebagai pengganti aturan dari Undang-Undang No. 22 Tahun 1999. Perubahan redaksional memang dilakukan oleh Undang-Undang No. 32 Tahun 2004, namun sama sekali tidak mengubah substansi. Pengaturan kewenangan daerah mengelola laut memang tidak dimulai dengan pengakuan bahwa wilayah propinsi terdiri atas wilayah darat, udara, dan laut. UndangUndang No. 32 Tahun 2004 tidak memiliki klausul semacam itu. Dalam Undang-Undang ini, pengaturan mengenai kewenangan daerah atas laut langsung mengasumsikan bahwa wilayah daerah mencakup juga wilayah laut. Oleh sebab itu, daerah-daerah yang memiliki wilayah laut dinyatakan memiliki kewenangan mengelola sumber daya di wilayah laut. Bukan hanya berwenang untuk mengelola, daerah juga berwenang untuk mendapatkan bagi hasil yang didapatkan dari aktivitas pengelolaan sumber daya alam di bawah dan/atau di dasar laut seperti UndangUndang No. 22 Tahun 1999, Undang-Undang No. 32 Tahun 2004 juga menyerahkan pengaturan lebih lanjut mengenai kewenangan daerah atas laut kepada Peraturan Pemerintah (yang selanjutnya disebut PP). Ikhtiar untuk membuat PP mengenai hal itu telah digagas cukup lama. Namun sampai Undang-Undang No. 22 Tahun 1999 digantikan oleh Undang-Undang No. 32 Tahun 2004 pada tahun 2004, pembahasan rancangan PP dimaksud (RPP tentang Kewenangan Daerah di Laut) tidak kunjung selesai. Secara yuridisnormatif, ketentuan mengenai kewenangan daerah atas laut yang diatur dalam Undang-Undang No. 22 Tahun 1999 dan Undang-Undang No. 32 Tahun 2004, diteruskan oleh semua undang-undang yang mengatur mengenai hal itu.

Pelaksanaan otonomi daerah sebagai perwujudan dari konsep desentralisasi pada dasarnya dimaksudkan agar pemerintah daerah dapat lebih meningkatkan daya guna dan hasil guna dalam menyelenggarakan pemerintahan, melaksanakan pembangunan, serta memberikan pelayanan kepada masyarakat secara lebih optimal, sesuai dengan karakteristik yang mana ada di wilayahnya. Dalam Undang-Undang No. 32 tahun 2004 tentang Pemerintahan Daerah dijelaskan bahwa pelaksanaan dari otonomi daerah diwujudkan dengan pemberian wewenang yang cukup luas, nyata, dan bertanggungjawab kepada pemerintah daerah secara proporsional melalui pengaturan, pembagian, pemanfaatan sumber daya yang berkeadilan serta perimbangan keuangan pusat dan daerah, dilandasi prinsip-prinsip demokrasi, peranserta masyarakat, pemerataan, keadilan, serta memperhatikan potensi dan keanekaragaman daerah.

Ruang Lingkup Undang-Undang No. 27 Tahun 2007 yang secara khusus mengatur Wilayah Pesisir dan juga Pulau-Pulau Kecil yang meliputi daerah pertemuan antara pengaruh perairan dan daratan, ke arah daratan mencakup wilayah administrasi dan ke arah perairan laut sejauh 12 (dua belas) mil laut diukur dari garis pantai ke arah laut lepas dan/atau ke arah perairan kepulauan. Lingkup pengaturan undangundang ini secara garis besar terdiri dari tiga bagian yaitu perencanaan, pengelolaan, serta pengawasan dan pengendalian. 
Pertama, Perencanaan yang dilakukan melalui pendekatan Pengelolaan Wilayah Pesisir dan juga melalui Pulau-Pulau Kecil yang terpadu (Integrated Coastal Management) yang mana mengintegrasikan berbagai perencanaan yang disusun oleh sektor dan daerah sehingga terjadi keharmonisan dan saling menguatkan dalam pemanfaatannya. Perencanaan wilayah pesisir dan juga pulau-pulau kecil dibagi ke dalam empat tahapan: rencana strategis; rencana zonasi; rencana pengelolaan; dan rencana aksi.

Kedua, Pengelolaan wilayah pesisir dan pulaupulau kecil mencakup tahapan kebijakan pengaturan antara lain pemanfaatan dan pengusahaan perairan pesisir dan pulau-pulau kecil dilaksanakan melalui pemberian izin pemanfaatan dan hak pengusahaan perairan pesisir.

Ketiga, Pengawasan dan Pengendalian dilakukan untuk: 1. Mengetahui akan adanya penyimpangan pelaksanaan rencana strategis, pelaksanaan rencana zonasi, rencana pengelolaan, serta juga implikasi penyimpangan tersebut terhadap perubahan kualitas ekosistem pesisir; 2. Mendorong agar pemanfaatan sumber daya di wilayah pesisir dan juga pulau-pulau kecil sesuai dengan rencana pengelolaan wilayah pesisirnya; 3. Memberikan sanksi terhadap pelanggar, baik berupa sanksi administrasi seperti pembatalan izin ataupun pencabutan hak, sanksi perdata seperti pengenaan denda atau ganti rugi, maupun sanksi pidana berupa penahanan atau pun kurungan.

Beberapa produk hukum yang mengatur reklamasi di wilayah pesisir dan pulau-pulau kecil antara lain adalah Undang-Undang No. 17 Tahun 2008 tentang Pelayaran, serta Undang-Undang No. 41 Tahun 1999 tentang Kehutanan, Peraturan Pemerintah No. 78 Tahun 2010 tentang Reklamasi dan Pasca Tambang, dan juga Peraturan Pemerintah No. 76 Tahun 2008 tentang Rehabilitasi dan Reklamasi Hutan. Selain itu Peraturan Pemerintah No. 38 tahun 2007 tentang Pembagian Urusan Pemerintahan antara Pemerintah, Pemerintahan Daerah Propinsi dan Pemerintahan Daerah Kabupaten/Kota telah mengatur kewenangan masing-masing sektor terkait dengan reklamasi agar dalam pelaksanaan reklamasi tidak menimbulkan konflik antar pemangku kepentingan.

Pada dasarnya, kegiatan akan reklamasi pantai tidaklah dianjurkan namun dapat dilakukan dengan memperhatikan isi ketentuan berikut (Departemen Pekerjaan Umum Direktorat Jenderal Penataan Ruang, 2008:7): 1. Merupakan kebutuhan pengembangan kawasan budi daya yang telah ada di sisi daratan; 2 . Merupakan bagian wilayah dari kawasan perkotaan yang cukup padat dan membutuhkan pengembangan wilayah daratan untuk mengakomodasikan kebutuhan yang ada; 3. Berada di luar kawasan hutan bakau yang merupakan bagian dari kawasan lindung atau taman nasional, cagar alam, dan suaka margasatwa; 4. Bukan merupakan kawasan yang berbatasan atau dijadikan acuan batas wilayah dengan daerah/negara lain.

Terhadap kawasan reklamasi pantai yang sudah memenuhi ketentuan di atas, terutama yang memiliki skala besar atau yang mengalami perubahan bentang alam secara signifikan perlu disusun Rencana Detail Tata Ruang (selanjutnya disebut RDTR) kawasan. Penyusunan RDTR kawasan reklamasi pantai ini dapat dilakukan bila sudah memenuhi persyaratan administratif berikut (Departemen Pekerjaan Umum Direktorat Jenderal Penataan Ruang, 2008:8): 1. Memiliki RTRW yang mana sudah ditetapkan dengan Perda yang mendeliniasi kawasan reklamasi pantai; 2. Lokasi reklamasi sudah ditetapkan dengan SK Bupati/Walikota, baik yang akan direklamasi maupun yang sudah direklamasi; 3. Sudah ada studi kelayakan tentang pengembangan kawasan reklamasi pantai atau kajian/kelayakan properti (studi investasi); d. Sudah ada studi AMDAL kawasan maupun regional.

Rencana detil tata ruang untuk kawasan reklamasi pantai meliputi rencana struktur ruang dan pola ruang. Struktur ruang di kawasan reklamasi pantai antara lain meliputi jaringan jalan, meliputi jaringan air bersih, jaringan drainase, jaringan listrik, jaringan telepon. Pola ruang di kawasan reklamasi pantai secara umum meliputi kawasan lindung dan kawasan budi daya. Kawasan lindung yang dimaksud dalam pedoman ini adalah ruang terbuka hijau. Kawasan budi daya meliputi kawasan peruntukan permukiman, kawasan perdagangan dan jasa, kawasan peruntukan industri, kawasan peruntukan pariwisata, kawasan pendidikan, kawasan pelabuhan laut atau penyeberangan, kawasan bandar udara, dan kawasan campuran.Oleh karena itu dalam perencanan reklamasi harus memenuhi beberapa aspek, antara lain (Departemen Pekerjaan Umum Direktorat Jenderal Penataan Ruang, 2008: 11):

Pertama, Aspek sosial, budaya, dan juga ekonomi kawasan: Tata ruang kawasan reklamasi pantai harus memperhatikan aspek sosial, ekonomi, dan budaya di kawasan reklamasi, sebagai berikut: a. Reklamasi pantai memberi dampak peralihan pada pola kegiatan sosial, budaya dan ekonomi maupun habitat ruang perairan masyarakat sebelum direklamasi. Perubahan terjadi haruslah menyesuaikan: 1) Peralihan fungsi kawasan dan pola ruang kawasan; 2) Selanjutnya, perubahan di atas itu berimplikasi pada perubahan ketersediaan jenis lapangan kerja baru dan bentuk 
keragaman/diversifikasi usaha baru yang ditawarkan; b. Aspek sosial, budaya, wisata, dan ekonomi yang diakumulasi dalam jaringan sosial, budaya, pariwisata, dan ekonomi kawasan reklamasi pantai memanfaatkan ruang perairan/pantai.

Kedua, Aspek pergerakan, aksesibilitas dan juga transportasi, perencanaan pergerakan, aksesibilitas dan transportasi kawasan reklamasi pantai harus memenuhi ketentuan sebagaimana berikut: a. Pola pergerakan kendaraan di ruas-ruas jalan, itu harus terintegrasi terhadap kerangka utama (coastal road) yang melintasi pantai atau perairan agar publik dapat menikmati panorama dan kenyamanan pantai; $b$. Tata ruang kawasan reklamasi pantai harus menyediakan kanal-kanal dan/atau ruang perairan lain, agar supaya aksesibilitas dan integrasi antara pusat kawasan dan sub-sub wilayah kota; c. Harus mudah diakses dan terintegrasi dengan sistem kota dari prasarana dan sarana di perairan, darat dan udara; d. Pola pergerakan dan transportasi darat dan perairan harus memiliki variasi integrasi dan variasi transportasi berdasarkan konsep ride and park system di beberapa tematik kawasan; e. Perencanaan akan manajemen sistem transportasi dan juga kelengkapan sarana penunjang transportasi.

Ketiga, Aspek kemudahan publik dan juga ruang publik. Untuk menjamin terwujudnya kemudahan publik di kawasan reklamasi pantai, perencanaan tata ruang kawasan ini harus memperhatikan: a. Tata letak bangunan yang figuratif dan garis ketinggian bangunan yang berhirarki untuk menjaga kemudahan publik dalam menikmati panorama ruang pantai; $b$. Keberadaan ruang publik yang mana dapat diakses, dimanfaatkan, dan juga dapat dinikmati secara mudah dan bebas oleh publik tanpa batasan ruang, waktu, dan biaya; c. Potensi elemen-elemen pantai untuk direpresentasikan kembali melalui kreatifitas proses penggalian, perancangan, dan pengemasan potensi alam/laut/pantai/perairan yang signifikan agar tercipta kemudahan dan kenyamanan publik; d. Potensi alam atau pantai yang kini perlu dikembangkan sekaligus dikonservasi, misalnya pasir, hutan, flora dan fauna air, bakau, tebing atau bibir pantai, kontur, peneduh, langit, dan pemandangan/panorama; e. Perwujudan kenyamanan pada elemen pantai dalam bentuk antara lain: keheningan suasana; keindahan panorama pantai; kealamiahan desa; kejernihan riak dan gelombang air pantai; kehijauan bukit dan lembah; kerimbunan hutan pantai; kebersihan pasir; kebiruan langit; keteduhan di sekitar wilayah pantai. Kemudahan publik dan ruang publik pada kawasan reklamasi pantai ditunjukkan pada Gambar 1.

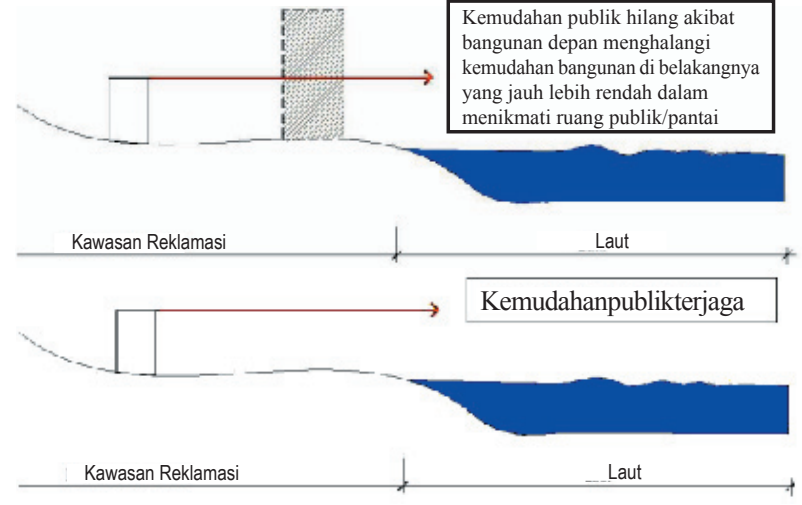

Gambar 1. Kemudahan Publik dan Ruang Publik

\section{Ketentuan Teknis Reklamasi}

Perencanaan tata ruang kawasan reklamasi pantai meliputi penetapan struktur ruang kawasan, pola ruang kawasan, pengelolaan lingkungan, prasarana dan sarana, serta fasilitas umum dan sosial. Maka perencanaan tata ruang kawasan reklamasi pantai tersebut harus memenuhi unsur-unsur yang berkaitan (Departemen Pekerjaan Umum Direktorat Jenderal Penataan Ruang, 2008:13). Perencanaan struktur ruang kawasan reklamasi pantai itu disusun dengan memperhatikan: 1. Sumbu-sumbu tata ruang kawasan yang memanfaatkan elemen pantai atau perairan sebagai garis poros/as kawasan secara visual atau pun secara konseptual; 2. Struktur ruang kawasan yang melewati di daerah paling tepi dari sekitar batas bibir pantai dengan daratan harus dipertahankan menjadi wilayah publik yang dapat dinikmati oleh masyarakat umum dengan mudah dimana Garis Sempadan Pantai itu (yang selanjutnya disebut GSP) bisa dimanfaatkan seperlunya untuk ruang terbuka; 3 . Pola struktur ruang kawasan yang melewati ruang perairan atau pantai dibuat sealamiah mungkin (linier lurus atau linier lengkung) dengan mempertahankan morfologi dan elemen-elemen ruang pantai yang ada.

Pola ruang kawasan reklamasi pantai disusun dengan memperhatikan: 1. Keseimbangan antara rencana pemanfaatan lahan untuk kepentingan fungsi budidaya dan lahan untuk fungsi lindung dengan memperhatikan kelestarian lingkungan hidup yang mencakup sumber daya alam dan buatan; 2 . Keseimbangan komposisi lahan pemanfaatan ruang antara ruang di daratan dengan perairan/tata biru/ pantai; 3. Peruntukan kawasan reklamasi pantai harus dimanfaatkan secara efektif, menghargai signifikansi ruang perairan, ada kesinergisan pola ruang kawasan budidaya dengan lingkungan alami disekitarnya; 4 . Pola ruang di sepanjang garis pantai yang merupakan wilayah GSP harus diarahkan menjadi ruang publik (jalan tepian pantai atau pun ruang terbuka) yang 
dapat diakses dan dinikmati publik; 5. Pola ruang kawasan diarahkan untuk mengakumulasi beberapa fungsi kawasan yang menghargai, menyatu dan memanfaatkan potensi pantai. Jaringan dan sistem infrastruktur/prasarana sarana dasar (PSD) dirancang mengikuti pola struktur ruang kawasan reklamasi. Rencana Induk Sistem (yang selanjutya disebut RIS) kawasan reklamasi pantai tersebut harus terintegrasi dengan sistem kota.

Pertama, Penyediaan jaringan jalan, jembatan, dan transportasi prasarana dan sarana jalan dan transportasi meliputi jaringan jalan dan jembatan, terminal, dan pelabuhan/dermaga yang dibutuhkan untuk menunjang aktifitas kawasan. Termasuk dalam perencanaan tersebut adalah penyediaan akan sarana angkutan umum untuk penumpang dan juga barang. Cara pengaturan jalan dan transportasi yang harus diperhatikan: a. Kebutuhan transportasi dan pola pergerakan lalu-lintas; b. Jenis moda dan intensitas yang diperlukan; c. Tingkat pelayanan dan fasilitas pelengkap yang dibutuhkan. Kedua, Penyediaan sistem drainase kawasan meliputi: saluran air hujan, saluran kolektor, bangunan pengendali banjir, polder, dan stasiun pompa; Ketiga, Penyediaan jaringan prasarana pengairan (air bersih, pemadam kebakaran, air kotor, dan air baku untuk keperluan kawasan); Keempat, Penyediaan jaringan prasarana energi untuk menunjang kebutuhan tenaga listrik kawasan; Kelima, Penyediaan jaringan prasarana telekomunikasi untuk meningkatkan kemudahan aktifitas kawasan; Keenam, Penyediaan jaringan persampahan.

Fasilitas umum dan sosial di kawasan reklamasi pantai meliputi pendidikan, kesehatan, perbelanjaan dan fasilitas niaga, pemerintahan dan pelayanan umum, peribadatan, rekreasi, kebudayaan, olahraga dan lapangan terbuka, serta fasilitas kegiatan umum dan sosial lainnya. Besaran penyediaan fasilitas umum dan sosial tersebut mengacu pada SNI 03-6981-2004 tentang Tata Cara Perencanaan akan Lingkungan Perumahan Sederhana Tidak Bersusun di Daerah Perkotaan. Secara umum jenis kawasan lindung yang dapat dikembangkan di kawasan reklamasi pantai adalah ruang terbuka hijau. Sedang kawasan budidaya yang dapat dikembangkan pada kawasan reklamasi pantai meliputi: Kawasan permukiman; perdagangan dan jasa; industri; Kawasan pariwisata; Kawasan pendidikan; Kawasan pelabuhan laut/penyeberangan; Kawasan bandara udara; Kawasan campuran.

\section{Teknik Dasar Reklamasi}

Ditilik berdasar lokasinya, pelaksanaan reklamasi pantai dibedakan menjadi dua yaitu (Nur Yuwono,
2007:14): Daerah reklamasi yang menyatu dengan garis pantai semula, dimana garis pantai yang baru akan menjadi lebih jauh menjorok ke laut; Daerah reklamasi yang memiliki jarak tertentu terhadap garis pantai. Sedangkan teknik dasar dan model reklamasi yang selama ini dilakukan memiliki tiga macam yaitu sistem Urugan, Polder, dan kombinasi Polder dan Urugan (Nur Yuwono, 2007:15):

Pertama, Sistem Urugan. Sistem urugan dalam pelaksanaannya adalah dengan mengurug laut antara tanggul samping batas reklamasi tanpa didahului pengeringan air terlebih dahulu. Dalam sistem ini setelah setelah urugan mencapai elevasi tertentu di atas permukaan air laut, maka dibuat tanggul penutup (garis tanggul sebidang dengan garis pantai) dan sisa timbunan di luar tanggul dibuang kembali.

Kedua, Sistem Polder. Sistem ini adalah dengan cara membuat tanggul di sekeliling daerah yang akan direklamasi, kemudian air laut dipompa atau dialirkan ke laut sehingga didapatkan suatu daratan baru yang lebih rendah dari permukaan laut tanpa dilakukan pengurugan. Sistem polder ini banyak dilakukan oleh negara Belanda dan umumnya juga diterapkan di daerah pantai yang mana bersifat daratan (daratan pantai pasang), penggunaannya lebih banyak untuk pertanian atau peternakan. Sistem ini memerlukan pompa secara terus menerus untuk menjaga muka air tanah. Kekuatan pompa harus memperhitungkan pula terhadap curah hujan di wilayah tersebut. Untuk daerah beriklim tropis yang curah hujan relatif tinggi, sistem ini tidak efektif.

Ketiga, Sistem Kombinasi. Sistem ini dengan cara membuat tanggul terlebih dahulu seperti dalam polder kemudian diurug. Karena jenis berat material urug yang lebih besar dari pada berat jenis air laut, maka air laut akan berangsur-angsur melimpah ke luar diganti oleh material urug sampai elevansi yang telah ditentukan.

Reklamasi merupakan kegiatan yang diperkirakan akan menimbulkan dampak yang besar sehingga perlu dibuat pedoman pelaksanaannya, pedoman ini bertujuan untuk: Pertama, Memberikan arahan dan acuan bagi Pemerintah, Pemerintah Daerah dan juga Masyarakat dalam rangka kegiatan reklamasi di wilayah pesisir yang berwawasan lingkungan.Kedua, Meningkatkan pemahaman pada semua pihak tentang kegiatan reklamasi di wilayah pesisir.

Pedoman Reklamasi di Wilayah Pesisir diatur dengan Keputusan Direktur Jenderal Pesisir dan juga Pulau-Pulau Kecil No. SK.64D/P3K/IX/2004 tentang Pedoman Reklamasi di Wilayah Pesisir. Pedoman ini diharap mampu mengakomodir semua kepentingan 
dan menciptakan keterpaduan di pantai yakni meliputi (Jacub Rais dkk, 2004:103): 1. Keterpaduaan antara sektor; sektor laut (perikanan, perlindungan biota laut, pariwisata pantai, pembangunan pelabuhan) dan sektor darat (pertanian); 2. Keterpaduan antara sisi darat dan air dari zona pantai; 3 . Keterpaduan antara tingkatan dalam pemerintah (nasional, subnasional, lokal); 4. Keterpaduan antarnegara; 5. Keterpaduan antara berbagai disiplin ilmu (seperti ilmu alam, ilmu sosial, dan teknik).

Tahap pelaksanaan reklamasi terdiri dari lima bagian, yaitu: perencanaan masterplan, kemudian studi kelayakan, rencana detail, konstruksi, serta monitoring dan evaluasi. Perencanaan masterplan harus mencakup dan memperhatikan hal-hal terkait dengan: Pertama, Keseimbangan ekologis: kondisi ekologi dan juga ekosistem pesisir yang sehat akan memastikan keberlanjutan kegiatan pemanfaatan yang dilakukan. Kedua, Kondisi fisik lokasi: Jaringan drainase, muara sungai, lidah pasir (sand split) dan juga migratori pulau pasir, delta, Hidro-oseanografi, geomorfologi, Fasilitas yang berada di sekitar lahan yang direklamasi, material urugan dan air tanah. Ketiga, Aspek hukum: hukum adat, hak atas tanah, hak atas pemanfaatan perairan. Keempat, yaitu aspek sosial ekonomi budaya yaitu: pranata sosial, aktivitas ekonomi, demografi, peran masyarakat dan daerah cagar budaya. Kelima, Aspek pemanfaatan wilayah dan juga sumberdaya di pesisir akan mempengaruhi keseimbangan dan kesehatan lingkungan baik karena limbah, konstruksi fisik maupun perubahan profil pesisir. Keenam, yaitu aspek pencegahan kerusakan ekosistem (mitigasi).

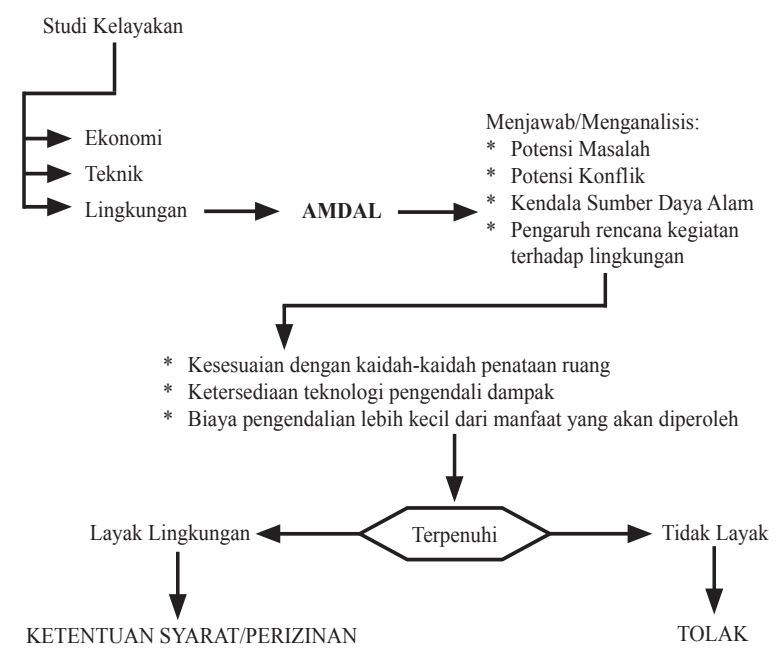

Bagan 1. Analisa mengenai AMDAL

Studi kelayakan meliputi kelayakan dari aspek teknis, aspek ekonomis-finansial, dan juga Analisis Mengenai Dampak Lingkungan (yang selanjutnya disebut AMDAL), hasil studi AMDAL yang dilakukan harus mengacu pada peraturan perundangan yang berlaku. AMDAL ini merupakan syarat mutlak dari bisa dilaksanakannya reklamasi atau tidak, karena studi ini akan dapat melihat sejauhmana manfaat dan dampak yang ditimbulkan dari proyek tersebut.

\section{Perlindungan Lingkungan Hidup terhadap Proses Reklamasi Pantai}

Reklamasi bagaimanapun telitinya direncanakan, tetap akan mengubah kondisi dan ekosistem pesisir, dan juga ekosistem buatan yang mana baru tentunya tidak akan sebaik yang alamiah. Secara garis besar reklamasi pantai memberikan dampak antara lain: Pertama, reklamasi pesisir demi memperoleh lahan lebih luas merupakan kegiatan paling buruk yang mengubah bentang asli pantai dan wilayah pesisir. Perubahan bentang alam ini akan berakibat pula terhadap perubahan akan hidro-oseanografi terutama arus dan gelombang laut yang tentunya akan menjadi ancaman besar bagi beberapa wilayah pesisir kota. Kedua, akan hilangnya potensi sumber daya hayati pesisir terutama beberapa biota laut yang selama ini dimanfaatkan oleh masyarakat nelayan, dan dampak selanjutnya adalah kemungkinan berkurangnya hasil tangkapan nelayan. Secara umum ekosistem seperti padang lamun, terumbu karang, dan lainnya diketahui memiliki fungsi ekologi yang sangat penting. Untuk itu, bila ekosistem pesisir ini rusak maka fungsi-fungsi tersebut di atas akan hilang, apalagi aktivitas seperti alih fungsi suatu wilayah pesisir, dimana secara fisik akan dapat mengalami tekanan yang sangat besar dan dampaknya akan semakin luas dan kompleks pula. Ketiga, kemungkinan besar akan terjadi perubahan dan perpindahan suplai sedimen yang sebelumnya tertampung pada wilayah reklamasi. Pengerukan dan juga penimbunan dalam proses reklamasi pantai dapat menyebabkan perubahan arus laut sekitarnya yang selanjutnya akan mengubah pola sedimentasi. Keempat, reklamasi berdampak terhadap rusaknya ekosistem mangrove dan juga terumbu karang, yang selanjutnya akan mengakibatkan penurunan kualitas lingkungan sumber daya ikan serta erosi pantai.

Pengelolaan lingkungan dalam perencanaan tata ruang kawasan reklamasi harus mempertimbangkan aspek lingkungan terutama dalam hal penggunaan energi, penggunaan sumber daya alam, pembukaan lahan, penanganan limbah. Hal ini bertujuan untuk meminimalkan dampak terhadap lingkungan.

Rujukan utama dalam pengelolaan lingkungan hidup di Indonesia ini adalah Undang-Undang No. 32 Tahun 2009 tentang Pengelolaan Lingkungan 
Hidup, yang secara regulatif melandasi kebijakan di Indonesia. Disini dijelaskan bahwa pengelolaan hidup diselenggarakan dengan asas tanggungjawab negara, keberlanjutan dan asas manfaat yang bertujuan untuk dapat mewujudkan pembangunan berkelanjutan yang berwawasan lingkungan hidup dalam rangka pembangunan manusia seutuhnya. Undang-undang ini menjamin dalam pelaksanaan pembangunan itu diharap adanya keselarasan hubungan antara manusia dengan manusia, manusia dengan lingkungan dan komponen lingkungan lainnya, serta dapat memenuhi masa kini dan menjaga kelestarian lingkungan di masa yang akan datang.

Pemanfaatan sumber daya dilaksanakan dengan bijaksana dengan tentu mempertimbangkan prinsip ekologi dan berwawasan lingkungan sehingga tidak mengakibatkan degradasi alam bahkan kerusakan lingkungan. Disamping mengatur hak, aturan dalam Undang-undang pengelolaan lingkungan hidup itu juga mewajibkan setiap orang untuk memelihara kelestarian fungsi dari lingkungan hidup, mencegah dan juga menanggulangi pencemaran dan perusakan lingkungan hidup serta dapat memberikan informasi yang benar dan juga akurat mengenai pengelolaan lingkungan hidup. Kewenangan harus diperhatikan keterpaduan antar stakeholder dalam pengelolaan lingkungan hidup, mengatur hubungan antara instansi pemerintah, swasta, masyarakat, serta komponenkomponen lainnya sehingga bisa berjalan seiring demi terciptanya lingkungan hidup yang baik. Untuk menjamin pelestarian fungsi lingkungan hidup, setiap rencana usaha yang dapat menimbulkan dampak besar wajiblah memiliki analisis mengenai dampak lingkungan hidup sebagai syarat untuk memperoleh izin melakukan usaha.

Dalam perspektif ekologi, semua rencana kegiatan yang diduga menimbulkan dampak besar dan penting wajib memiliki analisis mengenai AMDAL, tetapi dalam tataran praktis, kriteria untuk menetapkan jenis rencana kegiatan apa saja yang dapat dikategorikan menimbulkan dampak besar dan juga penting perlu pendekatan dalam perspektif regulasi AMDAL (http: //www.suaramerdeka.com/harian/0506/09/opi4.htm). Hal yang menjadi faktor terpenting dalam pelaksanaan reklamasi ini ialah dampak yang ditimbulkan dari pelaksanaan reklamasi tersebut. Sehingga, penting untuk melakukan monitoring mengenai pemenuhan standar kelayakan sebelum perencanaan reklamasi pantai.

Standar kelayakan tersebut meliputi kelayakan dari aspek teknis, aspek ekonomis-finansial, dan AMDAL, sedangkan hasil AMDAL yang dilakukan tersebut harus mengacu pada peraturan perundangan yang berlaku. AMDAL ini merupakan syarat mutlak untuk bisa dilaksanakannya reklamasi, karena studi mengenai AMDAL ini akan melihat sejauhmana manfaat dan dampak yang ditimbulkan dari proyek tersebut. Apabila hasil studi AMDAL menunjukkan kemungkinan akan timbulnya dampak negatif dari pelaksanaan kegiatan reklamasi tersebut, maka sudah selayaknya perencanaan reklamasi tersebut tidak dapat dilakukan. Namun pada prakteknya, seringkali studi AMDAL ini menjadi dinomorduakan atau bahkan diabaikan oleh pihak-pihak yang berkepentingan. Banyak terjadi, pengajuan perencanaan reklamasi di suatu daerah telah mendapat persetujuan dan izin dari pemerintah daerah sebelum dilakukannya studi AMDAL terhadap pengajuan rencana dari reklamasi tersebut. Seringkali pula kelalaian pemerintah dalam memeriksa AMDAL sebagai syarat utama pengajuan rencana reklamasi tersebut akhirnya menimbulkan dampak buruk terhadap masyarakat.

Terhadap permasalahan yang terjadi di dalam masyarakat yang seperti ini, maka selanjutnya upaya hukum yang dapat ditempuh untuk menyelesaikannya adalah masyarakat yang dirugikan atau yang jadi korban daripada kegiatan reklamasi pantai tersebut dapat mengajukan gugatan secara bersama-sama atau class action. Pemerintah kota juga berhak menuntut ganti rugi kepada pengembang atas kerusakan yang ditimbulkan. Sedangkan secara administratif, langkah hukum yang mana dapat dilakukan Pemerintah Kota terhadap kegiatan reklamasi yang tidak mendapat AMDAL yaitu dengan memerintahkan penghentian aktifitas reklamasi sampai ada AMDAL terhadap kegiatan tersebut.

Studi kelayakan meliputi kelayakan dari aspek teknis, aspek ekonomis-finansial dan AMDAL, hasil studi kelayakan lingkungan AMDAL yang dilakukan harus mengacu pada peraturan perundangan yang berlaku. AMDAL ini merupakan syarat mutlak dari bisa dilaksanakannya reklamasi atau tidak, karena studi ini akan dapat melihat sejauh mana manfaat dan dampak yang ditimbulkan dari proyek tersebut (Bapedal, 1996:36).

Dalam hal pelaksanaan dari tahapan konstruksi reklamasi, haruslah memperhatikan hal-hal sebagai berikut: Pertama, Pengerukan untuk proses reklamasi, baik di darat dan/atau di laut terdiri atas kegiatan: 1 . pembuatan bangunan semi permanen (bedeng kerja) bagi tempat tinggal sementara buruh/karyawan dan pembuatan prasarana lainnya; 2. pelaksanaan kegiatan pengerukan pasir atau juga lumpur; transportasi hasil pengerukan pasir atau lumpur ke tempat pembuangan 
dengan kapal keruk atau alat angkut lainnya. Kedua, Perataan dasar timbunan terdiri atas: 1. penyiapan lahan dan juga pembuatan bangunan semi permanen (bedeng kerja) bagi tempat tinggal sementara para buruh/karyawan dan pembuatan prasarana lainnya; 2. pelaksanaan kegiatan perataan dasar timbunan yang mana akan diterapkan, dengan memperhatikan metode penghancuran yang diterapkan dan jenis bahan yang digunakan; 3. kegiatan pembersihan dan juga perataan tanah dasar dari vegetasi dan kotoran lainnya; 4. kegiatan pembuatan talud penahan tanah (bila ada) dan pemecah gelombang (breakwater); 5. pemasangan silt screen di sekitar calon lahan reklamasi untuk menghindari menyebarnya partikel sedimen halus ke perairan di sekitar lokasi reklamasi; 6. kegiatan perbaikan tanah dasar (bilamana ada); 7. kegiatan penanganan dan penebaran material reklamasi dari darat atau dari laut; 8 . kegiatan pengeringan lahan reklamasi; 9. kegiatan perataan akan lahan reklamasi dengan alat berat; 10 . kegiatan pematangan lahan reklamasi; 11. kegiatan pengembangan dari sistem drainase; dan 12. kegiatan pengembangan dari lahan reklamasi.

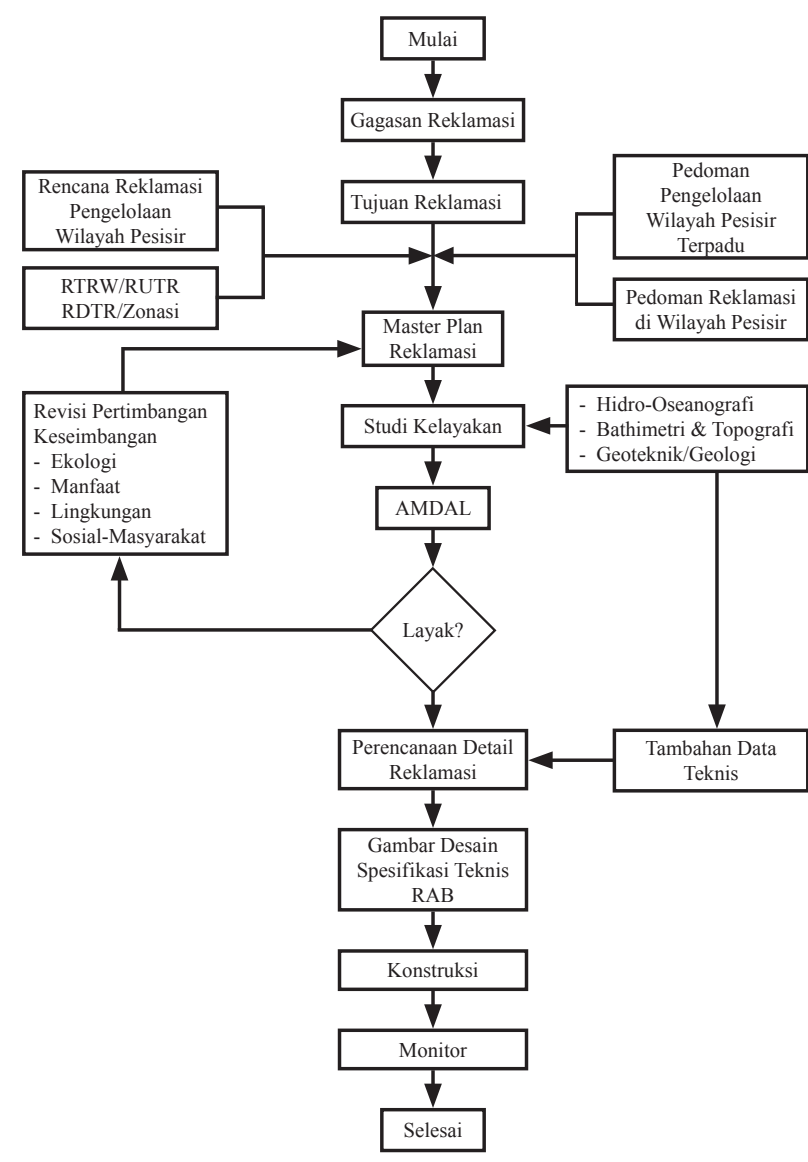

Bagan 2. Tahapan Pelaksanaan Reklamasi

Reklamasi adalah merupakan proyek yang besar yang membawa manfaat dan dampak yang tidak kecil, dari berbagai praktek reklamasi yang ada dan berbagai landasan hukum yang dijadikan acuan dalam realitanya dampak yang ditimbulkan dari reklamasi tidak bisa dianggap ringan. Reklamasi harus dapat menjamin keberlanjutan kehidupan dan penghidupan masyarakat berarti bahwa upaya reklamasi harus dapat meningkatkan kesejahteraan masyarakat sesuai dengan prinsip-prinsip pro job (pembukaan lapangan kerja), pro growth (pengembangan wilayah), dan pro poor (pengentasan kemiskinan). Reklamasi harus dapat menjaga keseimbangan antara kepentingan pemanfaatan dan juga kepentingan pelestarian fungsi lingkungan pesisir dan pulau-pulau kecil. Artinya, reklamasi yang dilakukan harus dengan berwawasan lingkungan.

\section{PENUTUP \\ Kesimpulan}

Sebagaimana telah dijelaskan dalam ketentuan dari Peraturan Menteri Pekerjaan Umum No. 40/PRT/ M/2007 tentang Pedoman Perencanaan Tata Ruang Kawasan Reklamasi Pantai, bahwa kegiatan reklamasi ini pada dasarnya tidak dianjurkan, namun demi kepentingan umum dengan memperhatikan segala manfaatnya maka reklamasi dapat diajukan asalkan sesuai ketentuan yang berlaku dan memperhatikan aspek yang terkait berikut dampak dan manfaatnya.

Pengelolaan mengenai wilayah pesisir khususnya yang menyangkut perencanaan, pemanfaatan, hak dan kewajiban, akses masyarakat, penanganan konflik, konservasi, mitigasi bencana, rehabilitasi kerusakan dan penjabaran dari pedoman reklamasi masih belum diatur.

\section{Rekomendasi}

Peraturan Daerah haruslah memberikan kepastian dan juga perlindungan hukum, memperbaiki tingkat kesejahteraan dari masyarakat wilayah pesisir melalui pembentukan peraturan yang dapat menjamin semua kepentingan stakeholder. Untuk itu, penting untuk dibuat peraturan di tingkat daerah yang mana mampu mewujudkan cita-cita bersama dalam pemanfaatan sumber daya alam yang ada di wilayah laut. Reklamasi merupakan suatu bagian kecil dan tak terpisahkan dari pengelolaan pesisir secara terpadu sehingga pelaksanaanya harus mengacu pada perencanaan pesisir secara menyeluruh dan tidak bisa dipisahkan. Namun yang harus diingat adalah untuk persoalan reklamasi belum ada payung hukum yang mana bisa dijadikan pedoman oleh daerah untuk pelaksanaannya. Dengan payung hukum, wilayah laut dan masyarakat wilayah pesisir akan semakin terlindungi. 


\section{DAFTAR PUSTAKA}

\section{Buku:}

Bapedal, 1996, Buku Panduan Penyusunan Amdal Kegiatan Pembangunan Wilayah Pesisir dan Lautan.

Departemen Kelautan dan Perikanan, 2001, Pedoman Umum Pengelolaan Pulau-pulau Kecil yang Berkelanjutan dan Berbasis Masyarakat, Jakarta: Ditjen Pesisir dan Pulau-pulau Kecil.

Direktorat Jenderal Kelautan, Pesisir dan PulauPulau Kecil, Departemen Kelautan dan Perikanan Indonesia, Pedoman Reklamasi di Wilayah Pesisir, Cetakan II, 2005.

Direktorat Pelabuhan dan Pengerukan Direktorat Jenderal Perhubungan Laut Departemen Perhubungan, Pedoman Teknis Kegiatan Pengerukan dan Reklamasi, Jakarta, Oktober 2006.

Farchan, M., 2008, Reklamasi sebagai Alternatif Kebijakan Pengelolaan Wilayah Pantai Kota Semarang, Semarang.

Iswahyuni, Nur Endah dan R. Slamet Santoso, Analisis Kebijakan Reklamasi Pantai Marina Semarang, Semarang.
Laidley, Jennefer, 2005, Constructing a Foundation for Change the Ecosystem Approach and The Global Imperative on Toronto's Central Water Front. Ontario: York University.

Maskur, Ali, 2008, Tesis Rekonstruksi Pengaturan Hukum Reklamasi Pantai di Kota Semarang, Semarang.

Rais, Jacub, dkk, 2004, Menata Ruang Laut Terpadu. Jakarta: Pradnya Paramita.

Yuwono, Nur, "Materi Bahasan Reklamasi", Makalah Lokakarya Nasional Pengelolaan Jasa Kemaritiman dan Kelautan, DKP, Jakarta, 20 Juni 2007.

\section{Peraturan Perundang-undangan}

Departemen Pekerjaan Umum Direktorat Jenderal Penataan Ruang, Peraturan Menteri Pekerjaan Umum No. 40/PRT/M/2007 tentang Kawasan Reklamasi Pantai, Jakarta, 2007.

\section{Website:}

http://www.ld-feui.org/page.php?lang=id\&menu=n ews_view\&news_id $=155$. 